\title{
Hackberry emperor, Asterocampa celtis (Boisduval \& Leconte) (Insecta: Lepidoptera: Nymphalidae: Apaturinae) ${ }^{1}$
}

Donald W. Hall and Jerry F. Butler ${ }^{2}$

\section{Introduction}

The hackberry emperor, Asterocampa celtis (Boisduval \& Leconte), is also known as the hackberry butterfly (Miller 1992) although the latter name is somewhat misleading because there are two other eastern United States butterflies--the American snout, Libytheana carinenta [Cramer], and the tawny emperor, Asterocampa clyton [Boisduval \& Leconte]--and also a number of other Asterocampa species, in other areas, that use hackberries as their exclusive caterpillar host plants (Scott 1986).

The hackberry emperor is a common butterfly of river bottoms and other areas where its host plants are common but it also may be found in upland areas.

Historically, dense swarms have been documented in some southern states (Lambremont 1984).

Detailed historical information on the taxonomy and nomenclature of the hackberry emperor is found in the Catalog of the Butterflies of the United States and Canada (Pelham 2008).

\section{Distribution}

The hackberry emperor is found from northeastern Mexico northward into the southwestern U.S. and to Nebraska and throughout most of the eastern U.S. except for the northern half of Wisconsin, Michigan and New York and all of New England (Opler and Krizek 1984, Opler et al. 2009). It is common in northern and central Florida but is infrequent in southern Florida (Minno et al. 2005).

\section{Description}

Adults: The wing spread of adults is 2.0 to 2.6 inches (Daniels 2003). Adults are somewhat variable regionally and the variants (races) are sometimes given subspecific names. The northern (and Florida panhandle) race is "celtis." The peninsular Florida race is designated "reinthali" (Cech and Tudor 2005, Minno and Minno 1999).

The upper surface of the wings is light brown with the distal half of the forewing darker. The hackberry emperor is readily distinguished from the

1. This document is EENY-453, one of a series of Featured Creatures from the Entomology and Nematology Department, Florida Cooperative Extension Service, Institute of Food and Agricultural Sciences, University of Florida. Published: June 2009. This document is also available on Featured Creatures Web site at http://creatures.ifas.ufl.edu. Please visit the EDIS Web site at http://edis.ifas.ufl.edu. Additional information on these organisms, including many color photographs, is available at the Entomology and Nematology Department website at http://entnemdept.ifas.ufl.edu/

2. Donald W. Hall, professor; Jerry F. Butler, professor; Department of Entomology and Nematology; Florida Cooperative Extension Service, Institute of Food and Agricultural Sciences, University of Florida, Gainesville, FL 32611.

The Institute of Food and Agricultural Sciences (IFAS) is an Equal Opportunity Institution authorized to provide research, educational information and other services only to individuals and institutions that function with non-discrimination with respect to race, creed, color, religion, age, disability, sex, sexual orientation, marital status, national origin, political opinions or affiliations. U.S. Department of Agriculture, Cooperative Extension Service, University of Florida, IFAS, Florida A. \& M. University Cooperative Extension Program, and Boards of County Commissioners Cooperating. Millie Ferrer, Interim Dean. 
closely related and similar tawny emperor by the white spots near the apex of the front wing and the sub-marginal black eyespot (also on the forewing), characters that are lacking in the tawny emperor. The ventral aspect of the hind wing is characterized by a row of post-median eyespots with powdery blue-green centers.

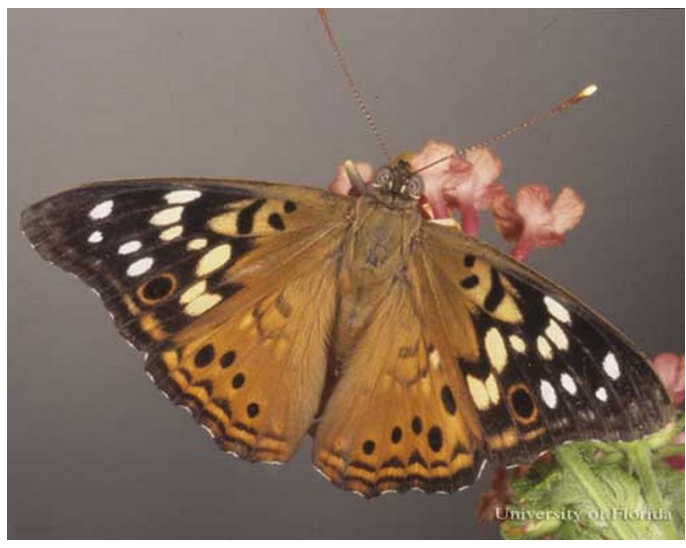

Figure 1. Dorsal wing view of an adult hackberry emperor, Asterocampa celtis (Boisduval \& Leconte). Credits: Jerry Butler, University of Florida

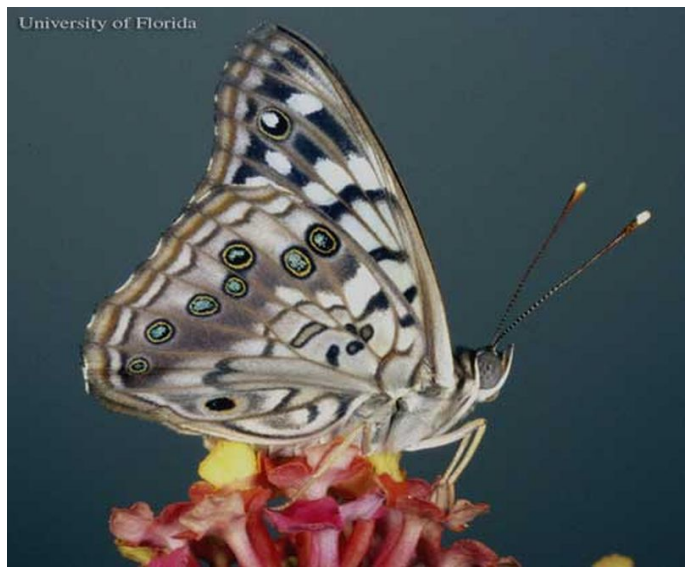

Figure 2. Ventral wing view of an adult hackberry emperor, Asterocampa celtis (Boisduval \& Leconte). Credits: Jerry Butler, University of Florida

Males are smaller and have narrower wings than females (Minno and Minno 1999).

Eggs: Eggs are white or pale yellow and surrounded by a series of vertical ridges.

Larvae: Full grown larvae are approximately 1.4 inches in length (Minno et al. 2005). The lower half of the head is green with short green spines laterally. The upper half of the head is brown with a pair of stout black horns dorsally. See Wagner (2005) for

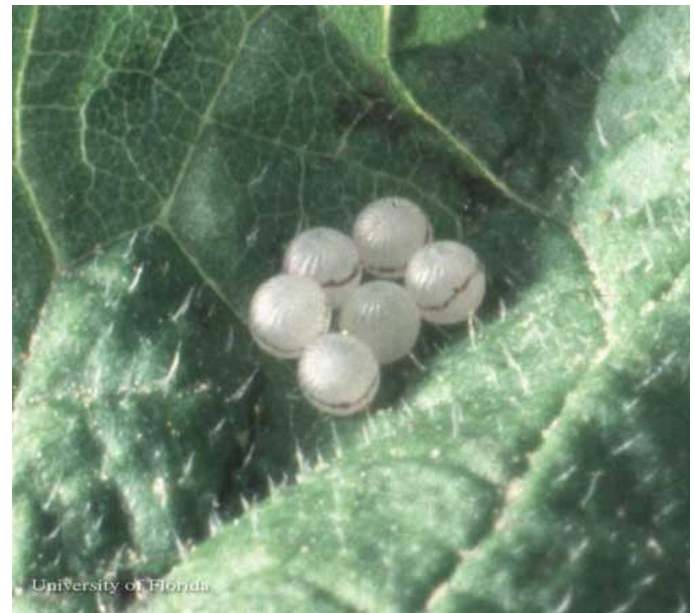

Figure 3. Eggs of the hackberry emperor, Asterocampa celtis (Boisduval \& Leconte). Credits: Don Hall, University of Florida

excellent drawings of the cephalic horns and lateral spines of the hackberry emperor and tawny emperor.

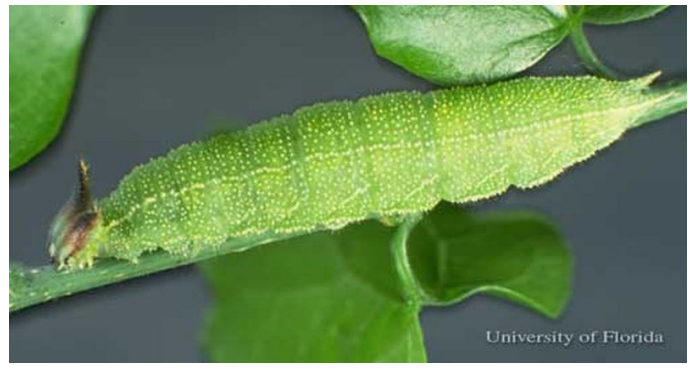

Figure 4. Larva of the hackberry emperor, Asterocampa celtis (Boisduval \& Leconte). Credits: Jerry Butler, University of Florida

The body has numerous tiny yellowish-white, raised, seta-bearing bumps (chalazae). Some of the chalazae are arranged to form narrow stripes on the back and sides. There are also oblique whitish-yellow stripes on the sides and two short tails on the posterior end.

Pupae: The pupae are green with small white spots and a white mid-ventral line that branches and runs to the tips of two horns at the anterior end of the pupa. There are also two white lateral lines and diagonal white lines on the sides of the abdomen. The pupae are attached to a silk pad by the cremaster.

\section{Life Cycle and Biology}

There are two generations per year throughout most of the range (Opler et al. 2009) and possibly three in Florida (Glassberg et al. 2000). 


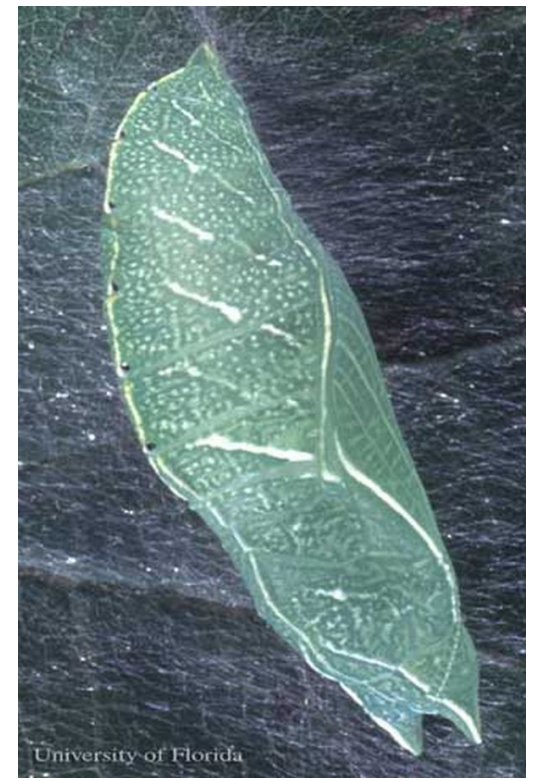

Figure 5. Pupa of the hackberry emperor, Asterocampa celtis (Boisduval \& Leconte). Credits: Jerry Butler, University of Florida

Adults have a very rapid flight. Males perch on foliage or other parts of the host plants to await females (Opler and Krizek 1984). A detailed description of the mating behavior is given by Langlois and Langlois (1964).

Females tend to be less active than males and are seen less frequently, but both sexes can be attracted to fermenting fruit baits. Adults feed on tree sap, fermenting fruit, dung, carrion, and rarely flower nectar (Opler and Krizek 1984). They also sip moisture and minerals from mud and readily land on people to drink sweat for salts (Allen 1997, Glassberg et al. 2000). Males are attracted to bright objects, and Glassberg et al. (2000) state that males can be attracted from their perches to land on pieces of white paper held in the sun.

Eggs are laid singly or in small groups on the undersides of leaves (Allen 2000, Opler and Krizek 1984, Scott 1986). Caterpillars rest on the undersides of leaves. They are particularly easy to see at night by shining a flashlight up into small trees. Third instars (probably even a few from the first generation [Opler and Krizek 1984, Cech and Tudor 2005]) attach to the undersides of leaves, turn brown and overwinter (diapause) in the rolled leaves (Allen 2000). According to Opler and Krizek (1984), the leaves with the diapausing larvae drop from the trees in the fall, and the larvae must then climb the tree to resume feeding in the spring. However, Minno and Minno (1999) state that the young larvae overwinter in leaf nests on the tree.

\section{Hosts}

The larval hosts of the hackberry emperor are hackberry trees (Celtis spp.) in the family Celtidaceae. The two most common hackberries in the eastern U.S., the more northern hackberry, Celtis occidentalis Linnaeus and the more southern sugarberry, Celtis laevigata Willd., can usually be recognized by the slightly to heavily warty appearance (or pronounced ridges on mature $C$. occidentalis) of the bark. More information and a key to the Celtis species is available at efloras.org (undated).

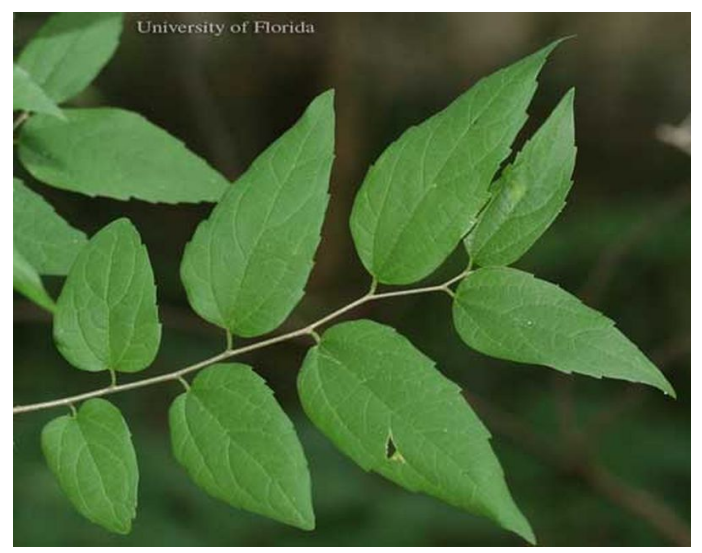

Figure 6. Sugarberry, Celtis laevigata Willd., a host of the hackberry emperor, Asterocampa celtis (Boisduval \& Leconte). Credits: Don Hall, University of Florida

\section{Economic Importance}

Hackberry emperor larvae are rarely numerous enough to seriously affect host trees. However, there are accounts of complete defoliation of both $C$. occidentalis (Langlois and Langlois 1964) and $C$. laevigata (Solomon et al. 1975). Control measures are not required.

\section{Selected References}

- Allen TJ. 1997. The Butterflies of West Virginia and their Caterpillars. University of Pittsburgh Press. Pittsburgh, Pennsylvania. 400 pp. 


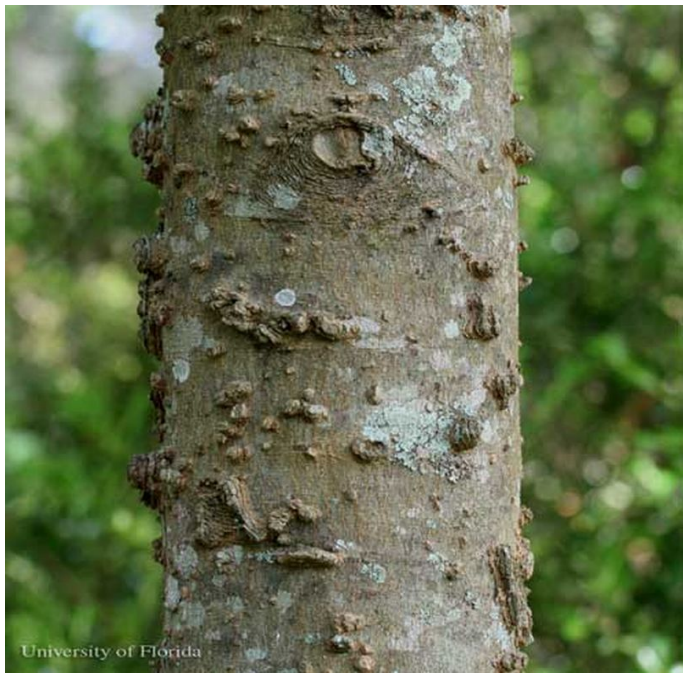

Figure 7. Warty trunk of the sugarberry, Celtis laevigata Willd., a host of the hackberry emperor, Asterocampa celtis (Boisduval \& Leconte). Credits: Don Hall, University of Florida

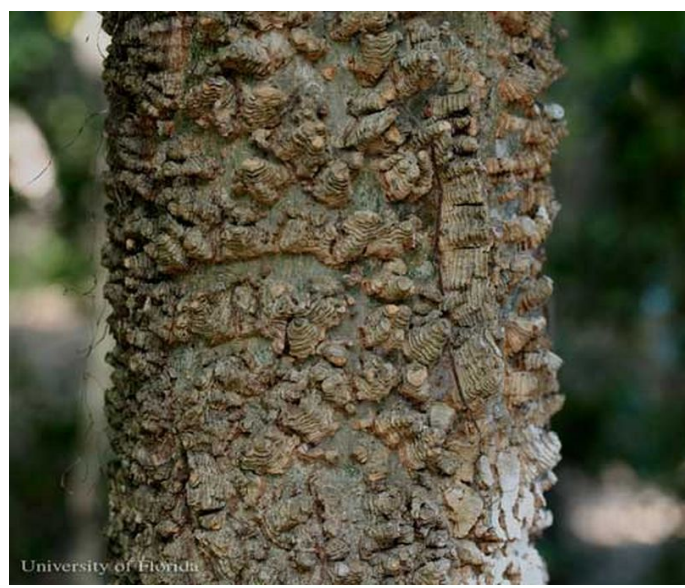

Figure 8. Heavily warty trunk of the sugarberry, Celtis laevigata Willd., a host of the hackberry emperor, Asterocampa celtis (Boisduval \& Leconte). Credits: Don Hall, University of Florida

- Cech R, Tudor G. 2005. Butterflies of the East Coast: An Observer's Guide. Princeton University Press. Princeton, New Jersey. 345 pp.

- Daniels JC. 2003. Butterflies of Florida: Field Guide. Adventure Publications, Inc. Cambridge, Minnesota. $256 \mathrm{pp}$.

- Efloras.org. (Undated). Celtis Linnaeus, Sp. Pl. 2: 1043. 1753; Gen. Pl. ed. 5, 467, 1754. Flora of North America. http://efloras.org/ florataxon.aspx?flora_id=1\&taxon_id=105995 (18 May 2009).
- Glassberg J, Minno C, Calhoun JV. 2000. Butterflies through Binoculars: Florida. Oxford University Press. New York, New York. 256 pp.

- Lambremont EN. 1984. Hackberry butterflies: dense swarms involved in a litigation in southern Louisiana (Nymphalidae: Asterocampa). Journal of the Lepidopterists' Society 38: 252-253.

- Langlois TH, Langlois MH. 1964. Notes on the life-history of the hackberry butterfly, Asterocampa celtis (Bdvl. \& Lec.) on South Bass Island, Lake Erie. The Ohio Journal of Science 64: 1-11.

- Miller JY, ed. 1992. The Common Names of North American Butterflies. Smithsonian Institution Press. Washington, D.C. 177 pp.

- Minno MC, Butler JF, Hall DW. 2005. Florida Butterfly Caterpillars and their Host Plants. University Press of Florida. Gainesville, Florida. $341 \mathrm{pp}$.

- Minno MC and Minno M. 1999. Florida Butterfly Gardening: A Complete Guide to Attracting, Identifying, and Enjoying Butterflies of the Lower South. University Press of Florida. Gainesville, Florida. 210 pp.

- Opler, PA, Lotts K, Naberhaus T. (2009). Butterflies and Moths of North America. http://www.butterfliesandmoths.org/ (18 May 2009).

- Opler PA, Krizek GO. 1984. Butterflies East of the Great Plains. The Johns Hopkins University Press. Baltimore, Maryland. 294 pp.

- Pelham JP. 2008. A Catalog of the Butterflies of the United States and Canada with a Complete Bibliography of the Descriptive and Systematic Literature. Journal of Research on the Lepidoptera Vol. 40, 658 pp.

- Scott JA. 1986. The Butterflies of North America: A Natural History and Field Guide. Stanford University Press. Stanford, California. $583 \mathrm{pp}$. 
- Solomon JD, Vowell TE, Jr., Horton RC. 1975.

Hackberry butterfly, Asterocampa celtis,

defoliates sugarberry in Mississippi. Journal of the Georgia Entomological Society 10: 17-18.

- Wagner DL. 2005. Caterpillars of Eastern

North America. Princeton University Press.

Princeton, New Jersey. 512 pp. 